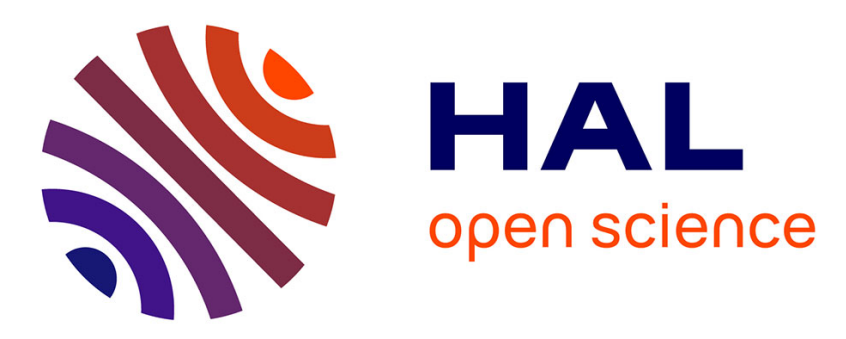

\title{
The effect of different concentrations of oxalic acid in aqueous and sucrose solution on Varroa mites and honey bees
}

\author{
Kalle Toomemaa, Ants-Johannes Martin, Ingrid H. Williams
}

\section{- To cite this version:}

Kalle Toomemaa, Ants-Johannes Martin, Ingrid H. Williams. The effect of different concentrations of oxalic acid in aqueous and sucrose solution on Varroa mites and honey bees. Apidologie, 2010, 41 (6), 10.1051/apido/2010029 . hal-00892065

\section{HAL Id: hal-00892065 https://hal.science/hal-00892065}

Submitted on 1 Jan 2010

HAL is a multi-disciplinary open access archive for the deposit and dissemination of scientific research documents, whether they are published or not. The documents may come from teaching and research institutions in France or abroad, or from public or private research centers.
L'archive ouverte pluridisciplinaire HAL, est destinée au dépôt et à la diffusion de documents scientifiques de niveau recherche, publiés ou non, émanant des établissements d'enseignement et de recherche français ou étrangers, des laboratoires publics ou privés. 


\title{
The effect of different concentrations of oxalic acid in aqueous and sucrose solution on Varroa mites and honey bees*
}

\author{
Kalle TOOMEMAA, Ants-Johannes MARTIN, Ingrid H. WiLliams \\ Institute of Agricultural and Environmental Sciences, Estonian University of Life Sciences, 1A Kreutzwaldi St, \\ 51014 Tartu, Estonia
}

Received 15 April 2009 - Revised 15 December 2009 - Accepted 21 December 2009

\begin{abstract}
The toxicity of various concentrations of oxalic acid dihydrate (OA) in aqueous and sucrose solution to Varroa destructor and to honey bees (Apis mellifera) was assessed using submersion tests of caged bees and by spraying bees in colonies with and without brood. An aqueous solution of $0.5 \%$ OA gave effective control of the mite and was non-toxic to bees whereas higher concentrations of OA (1.0-2.0\%) were highly toxic to bees. Submersion tests into solutions with $0.1 \%$ OA were acaricidal both in aqueous $(59.9 \pm 3.7 \%)$ and in $50 \%$ sucrose solution $(71.1 \pm 4.2 \%)$ whereas concentrations of $0.2-0.5 \%$ OA were highly effective; OA in sucrose solution was more toxic to bees than OA in the aqueous solution. Spraying with $0.5 \%$ OA solution at a dose of $25 \mathrm{~mL}$ per comb in May 2003 and in April 2004 was 99.01-99.42\% effective in mite control in Estonian standard one box long beehives with 22 frames (each $414 \times 277 \mathrm{~mm}$, area $1000 \mathrm{~cm}^{2}$ per comb side). Most mites fell after the first spraying. In autumn, spraying test colonies that had little capped brood once or twice with a $0.5 \%$ OA solution gave effective mite control $(92.94 \pm 0.01 \%$ and $91.84 \pm 0.02 \%$, respectively) with no noticeable toxicity to bees.
\end{abstract}

Apis mellifera / honey bee / Varroa destructor / oxalic acid

\section{INTRODUCTION}

Spraying bees with a weak aqueous solution of oxalic acid (OA) has been used to control the mite, Varroa destructor, since the 1980's. Takeuchi and Harada (1983a) first reported that $2 \% \mathrm{OA}$ in aqueous solution, at a dose of $100-150 \mathrm{~mL}$ per colony, was very effective against the mite and at the same time harmless to bees. Subsequently it was reported that even spraying four times did not ensure complete control of the mite, and that better results were achieved by spraying once with $300 \mathrm{~mL}$ per colony (Takeuchi and Sakai, 1985). More recently, spraying 5-8 mL of $3 \%$ OA solution per comb has been recommended (Radetzki et al., 1994). A single spray applied during a brood-free period was

Corresponding author: A.-J. Martin, ants.martin@emu.ee

* Manuscript editor: Peter Rosenkranz on average 94.5-98.8\% (Imdorf et al., 1997) and $97.29 \%$ (Radetzki et al., 1994) effective against the mite, whereas spraying twice was up to $99.5 \%$ effective (Nanetti et al., 1995). Usually, no negative toxic effects have been observed on bees, even when a 5\% OA solution was sprayed and higher doses $(20 \mathrm{~mL}$ per comb) were used (Radetzki et al., 1994). However, some negative after effects have been reported, such as a decrease in brood area after spraying four-times (Higes et al., 1999).

Current practice, widespread throughout the world, involves trickling a sucrose solution containing OA into the spaces between combs covered with bees, as it is highly effective, simple and cheap. In brood-free periods in autumn, the efficacy of a single trickling treatment has exceeded 90\% (Nanetti et al., 2003) and, in some cases, even 99\% (reviewed by Rademacher and Harz, 2006). Trickling three times in the presence of brood resulted in 
95\% efficacy in autumn (Mutinelli et al., 1997) and $39.2-52.3 \%$ in summer, or $44 \%$ on average (Gregorc and Planinc, 2001). However, trickling in summer was highly toxic to bees (Rademacher and Harz, 2006). The lowest effective oxalic acid dihydrate concentration has been reported to be $30 \mathrm{~g} / \mathrm{L}$; this is only slightly less effective than higher concentrations. Others have reported that trickling may also cause loss of bees in winter (Charriere and Imdorf, 2002; Nanetti et al., 2003).

The effect of solutions containing less than $2 \%$ OA has been little studied so far. Aqueous oxalic acid solutions in concentrations of 1.7 and $1.4 \%$ have been reported to kill Varroa mites whereas a $0.7 \%$ aqueous solution had no effect (Takeuchi and Sakai, 1983b). A $3 \%$ aqueous solution (Higes et al., 1999) and sucrose solutions of the same or higher concentrations were reported to be toxic to bees; others found that the $3 \%$ concentration weakened colonies in the winter following treatment, particularly after two or three treatments during the summer or autumn (Rademacher and Harz, 2006). Gregorc et al. (2004) reported a level of $82 \%$ cell death of midgut epithelium in honey bee larvae $50 \mathrm{~h}$ after spraying OA in sucrose solution $(2.97 \% / 31.95 \%$, $\mathrm{w} / \mathrm{v}$ ) directly onto uncapped brood. Increased levels of larval mortality were found after two treatments with $\mathrm{OA}$ in sucrose solution $(3.0 \% / 50 \%, \mathrm{w} / \mathrm{v})$ in summer; the area of uncapped brood was reduced by $17.5 \%$ and remained low for about two months (Hatjiana and Haristos, 2005). Despite extensive recent research, optimum OA concentrations and the amount of OA per comb have not been established. The aim of our present study was to determine the concentration of oxalic acid solution that would combine good control of the mite with low bee mortality.

\section{MATERIAL AND METHODS}

Seven experiments were conducted to test a range of oxalic acid concentrations for their toxicity to Varroa mites and honeybees. Solutions for testing were prepared by dissolving a known weight of oxalic acid dihydrate in either distilled water or a $50 \%$ sucrose solution. Two methods of application of the solutions were compared: (1) submersion tests of bees from infested hives enclosed in cages; and (2) spraying tests of bees on combs. In the submersion tests, $100 \mathrm{~g}$ of bees in cages were submerged into one of a range of solutions. The spraying tests were carried out at an apiary in West-Viru County, Estonia. The bees were housed in Estonian standard one-box long hives with a frame size of $414 \times 277 \mathrm{~mm}$ and an area per comb side of $1000 \mathrm{~cm}^{2}$. Hives were provided with screened bottom boards. In the spraying tests, the solutions were sprayed directly onto bees on combs removed from the hives, using a hand-operated atomizer, and then replaced. The strength of each colony was estimated according to the Liebefeld method (Gerig, 1983; Imdorf et al., 1987) before and after the spraying experiments. Seven days after the last spraying, dead mites were counted and colony strength was estimated again. Apistan ${ }^{\circledR}$ strips were then placed in each test and control colony to determine the number of mites that had survived the test. A strip was placed into each comb space, but not in the end spaces, for 6 days after which mites were counted that had fallen onto the sheet of paper placed under the screened bottom board. In determining the effectiveness of the control, the cumulative mite-fall after oxalic acid and subsequent control treatment was assumed to be $100 \%$.

\subsection{Submersion tests in the laboratory}

\subsubsection{Experiment 1: aqueous solutions with $0.5,1.0,1.5$ and $2.0 \% O A$ (July 2002)}

Bees were collected from the brood combs of each experimental colony and $100 \mathrm{~g}$ of bees were placed into each of five stainless wire-mesh cages $(100 \times 80 \times 100 \mathrm{~mm})($ Tab. I). One test cage for each concentration and one control cage was used for each test series. Each test cage with bees was submerged into a solution of OA of known concentration at $25^{\circ} \mathrm{C}$, and spun around the horizontal axis for 8 seconds to let air bubbles out before being removed from the solution. Each cage was then held above the bath for 10 seconds before being resubmerged into the solution for 8 seconds and spun again to wet the bees more thoroughly. The control cage with bees was submerged in water in the same manner. The caged bees were then kept for 48 hours at $25{ }^{\circ} \mathrm{C}$ and fed with honey. Fallen and dead mites were counted periodically, and dead and injured bees on the bottom of cages were counted 
Table I. Methods of treatments with OA in aqueous- and sucrose solutions.

\begin{tabular}{|c|c|c|c|c|c|c|c|c|c|}
\hline $\begin{array}{l}\text { Variant of } \\
\text { experiment }\end{array}$ & $\begin{array}{l}\text { Number of } \\
\text { experiment }\end{array}$ & $\begin{array}{c}\text { Time of } \\
\text { experiment }\end{array}$ & $\begin{array}{c}\text { Concentration } \\
\text { of OA, } \%\end{array}$ & $\begin{array}{c}\text { Dose per } \\
\text { comb, mL }\end{array}$ & $\begin{array}{l}\text { Number of } \\
\text { treatments }\end{array}$ & $\begin{array}{c}\text { Interval } \\
\text { treatments, } \\
\text { between } \\
\text { days }\end{array}$ & $\begin{array}{l}\text { Number of } \\
\text { replications }\end{array}$ & $\begin{array}{l}\text { Presence of } \\
\text { brood, }+,-\end{array}$ & $\begin{array}{c}\text { Aqueous }(\mathrm{A}) \\
\text { or sucrose }(\mathrm{S}) \\
\text { solution }\end{array}$ \\
\hline \multirow{9}{*}{ Submersion } & 1 & July, 2002 & 0.5 & & 2 & & 10 & - & $\mathrm{A}$ \\
\hline & & & 1.0 & & 2 & & 10 & - & A \\
\hline & & & 1.5 & & 2 & & 10 & - & A \\
\hline & & & 2.0 & & 2 & & 10 & - & A \\
\hline & 2 & July, 2007 & 0.1 & & 2 & & 5 & - & A, S \\
\hline & & & 0.2 & & 2 & & 5 & - & $\mathrm{A}, \mathrm{S}$ \\
\hline & & & 0.3 & & 2 & & 5 & - & $\mathrm{A}, \mathrm{S}$ \\
\hline & & & 0.4 & & 2 & & 5 & - & $\mathrm{A}, \mathrm{S}$ \\
\hline & & & 0.5 & & 2 & & 5 & - & $\mathrm{A}, \mathrm{S}$ \\
\hline \multirow{7}{*}{ Spraying } & 3 & April, 2003 & 0.5 & 25 & 4 & $3-6$ & 3 & - & $\mathrm{A}$ \\
\hline & & & 1.0 & 25 & 4 & $3-6$ & 3 & - & A \\
\hline & & & 1.5 & 25 & 4 & $3-6$ & 3 & - & A \\
\hline & 4 & May, 2003 & 0.5 & 25 & 5 & 1 & 6 & - & A \\
\hline & 5 & April, 2004 & 0.5 & 25 & 5 & 1 & 11 & - & A \\
\hline & 6 & Sept., 2005 & 0.5 & 25 & 1 and 2 & 6 & 15 & + & A \\
\hline & 7 & Sept., 2006 & 0.3 & 25 & 1 & & 8 & + & A \\
\hline
\end{tabular}

at the end of the experiment. After two days, half a strip of Apistan was placed in each test and control cage to determine the number of mites that had survived the treatment. As Apistan strips had never been used before in the control of Varroa mites in the experimental apiary, the risk of mite resistance to Apistan was low. The experiments were replicated 10 times, with four different concentrations and one control for each test series

\subsubsection{Experiment 2: aqueous versus sucrose solutions with $0.1,0.2,0.3$, 0.4 and $0.5 \%$ OA (July 2007)}

The submersion method used was as for Experiment 1 . The control group was similarly submerged into either an aqueous or a sucrose solution (50\%) without any OA. After submersion into the sucrose solutions the cages was washed in hot water $\left(35^{\circ} \mathrm{C}\right)$ to release mites that had stuck to the cages. The experiments with different concentrations were replicated 5 times (Tab. I).

\subsection{Spraying tests onto bees in colonies}

\subsubsection{Experiment 3: aqueous solutions with 0.5, 1.0 and $1.5 \% \mathrm{OA}$ (April 2003)}

A total of 12 colonies were used with three test hives and a control colony in each of three exper- imental groups (Tab. I). The brood was cut out of the brood comb and the queens were caged to prevent egg-laying prior to treatment. Test colonies were sprayed with different concentrations of OA aqueous solution at 3-6 day intervals depending on the weather; control colonies were sprayed with the same amount of water. The bees were sprayed until wetted. A dosage of $25 \mathrm{~mL}$ per comb was used. The bees out of the sprayed combs were given an additional spray with $25 \mathrm{~mL}$ OA solution. Thus, for an 8 -frame colony, $8 \times 25+25=225 \mathrm{~mL}$ solution of OA was applied.

\subsubsection{Experiment 4: aqueous solution with 0.5\% OA (May 2003)}

Five test colonies and three control colonies were used (Tab. I). The queens in each colony were caged on 15 April, and the experiment started when all the brood had emerged (three weeks later).

\subsubsection{Experiment 5: aqueous solution with 0.5\% OA (April 2004)}

Eleven test colonies and five control colonies were used (Tab. I). The queens in these colonies were caged on 15 March. Dead mites were counted two days after each spraying. Colony strength was estimated again after the third and fifth spraying and again 12 days later to determine bee tolerance. 


\subsubsection{Experiment 6: aqueous solution with $0.5 \%$ OA (September 2005)}

Forty colonies were split into two groups, each having 15 test colonies and five control colonies (Tab. I). The area of capped brood was assessed in each colony. Group 1 test colonies were sprayed once and group 2 twice over a 6-day interval. The following spring (30 March 2006), colony strength was reassessed and mite survival assessed.

\subsubsection{Experiment 7: aqueous solution with $0.3 \%$ OA (September 2006)}

The test group was comprised of eight colonies and the control group five colonies (Tab. I). The area of capped brood in each colony was assessed.

For statistical analyses one-way ANOVA was employed using Statistica 7.0. Means were compared using the LSD Test, and $t$-tests were applied at a significance level of $P<0.05$. A multiple linear regression was used to determine the effectiveness of spraying the colonies with various capped brood area.

\section{RESULTS}

\subsection{Submersion experiments}

Experiment 1 submersion tests showed that all concentrations of $\mathrm{OA}$ in the range of $0.5-2 \%$ were equally toxic to Varroa mites but that $1.0 \%$ and stronger OA solutions were toxic to bees (Fig. 1). The $0.5 \%$ aqueous OA solution was non-toxic to bees, the $1.0 \%$ solution caused the death of a small number, and concentrations of 1.5 and $2.0 \%$ were highly toxic to bees.

Experiment 2 submersion tests showed that a $0.1 \%$ OA concentration killed mites (Fig. 2). The aqueous OA solution was $59.9 \pm 3.72 \%$ effective while the sucrose solution was slightly, but not significantly more effective at $71.1 \pm$ $4.20 \%$ ( $t$-test: $t=-1.885, P=0.096$, $\mathrm{df}=8)$. More concentrated solutions of OA $(0.2 \%)$ were more effective: $89.77 \pm 2.18 \%$ in aqueous solution and $90.03 \pm 1.03 \%$ in sucrose solution, respectively. Effectiveness of the $0.3 \%$ concentration in aqueous solution was $94.89 \pm 0.93 \%$ and in sugar solution

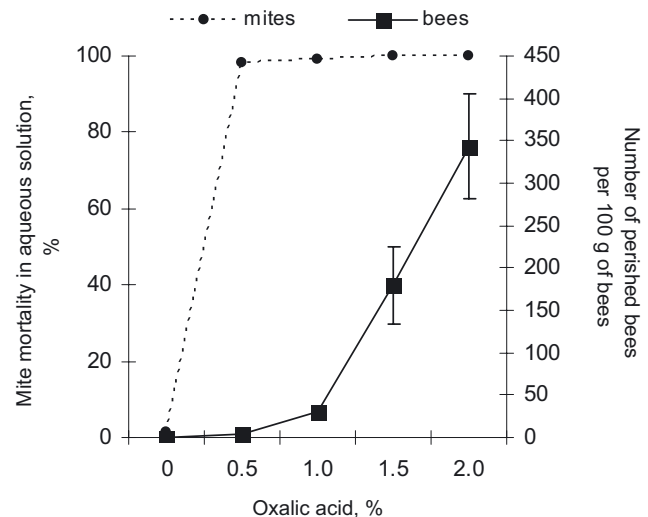

Figure 1. Effect of $0.5,1.0,1.5$ and $2.0 \%$ oxalic acid dihydrate (OA) in aqueous solution on Varroa mites and bees in submersion tests $(\mathrm{n}=10$ experimental series) at the end of July 2002. Data are presented as means \pm standard errors. Concentrations of $0.5-2.0 \%$ had similar toxicity to the mites. The $0.5 \%$ concentration showed little toxicity to bees but toxicity to bees increased considerably with concentrations higher than $1.0 \% \mathrm{OA}$.

was $95.51 \pm 0.54 \%$, which were statistically similar. Both the $0.4 \%$ and $0.5 \%$ aqueous and sucrose solutions achieved up to $100 \%$ effectiveness (Fig. 2 A, B) (ANOVA, LSD test, for water solution $\mathrm{F}_{4 ; 20}=69.5849, P=0.00$, for sugar solution $\left.\mathrm{F}_{4 ; 20}=38.1801, P=0.00\right)$. The OA in sucrose showed slightly, but not significantly, higher mite control than the OA in water (Figs. 2 A, B), but was considerably more toxic to bees (Fig. 3). The $0.3 \%$ OA solution in sucrose was five times more lethal to bees than that in water. The increase in concentration from $0.4 \%$ to $0.5 \%$ of $\mathrm{OA}$ in sucrose solution increased the mortality of bees about five times more than the aqueous solution with the same concentration of OA, a killing significant number of bees (Fig. 3, $P<0.05$, $t$-test). Aqueous OA solutions were milder; at concentrations of $0.1-0.4 \%$ only a few bees died, but the $0.5 \%$ concentration caused the death of $35 \pm 5$ bees on average (ANOVA, LSD test, for aqueous solution $\mathrm{F}_{5 ; 24}=8.287, P=0.00$, for sucrose solution $\left.\mathrm{F}_{5 ; 24}=30.003, P=0.00\right)$. About $90 \%$ of all mites were dead within 24 hours after submersion into $0.5 \%$ OA solution. Solutions weaker than $0.5 \%$ solutions had a slower effect. 

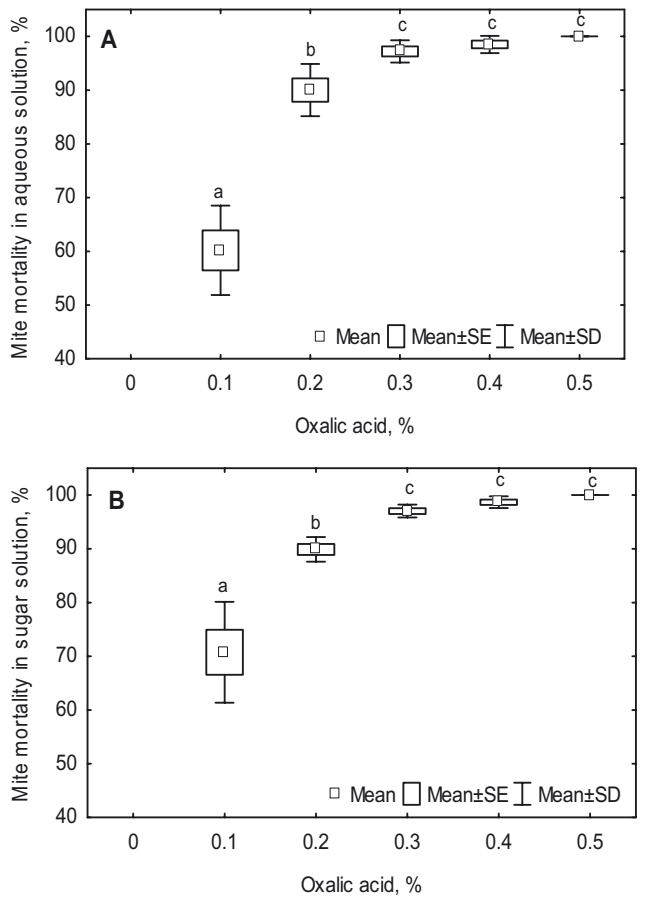

Figure 2. Effect of $0.1-0.5 \%$ oxalic acid dihydrate $(\mathrm{OA})$ in aqueous (A) and in $50 \%$ sucrose solution (B) on mite mortality in submersion tests $(\mathrm{n}=$ 5 experimental series) at the end of July 2007. Different letters indicate statistically significant differences (ANOVA one-way, LSD test, aqueous solution $\mathrm{F}_{4 ; 20}=69.5849, P=0.000$; sucrose solution $\left.\mathrm{F}_{4 ; 20}=38.1801, P=0.000\right)$. There was little difference between the effectiveness of the $\mathrm{OA}$ in aqueous and sucrose solution at $0.1-0.5 \%$ concentrations of OA. Higher acaricidal activity was found only in the concentration of $0.1 \%$ in aqueous solution compared to the same concentration in sugar solution.

\subsection{Spraying experiments}

Experiment 3, in which bees in brood-free colonies were sprayed four times in early spring (April) with 0.5 to $1.5 \% \mathrm{OA}$ in aqueous solution (Fig. 4) confirmed the results of the submersion test (Experiment 1) (Fig. 1). Solutions of 1.0 and $1.5 \%$ OA gave similar mite control $(98.39 \pm 0.01 \%$ and $98.28 \pm 0.01 \%)$; the $0.5 \%$ aqueous solution gave a weaker, but significant effect $(94.92 \pm 0.00 \%)$ (ANOVA, LSD test, $\mathrm{F}_{3 ; 8}=4466.64, P=0.00$ ) (Fig. 4). However, the 1.0 and $1.5 \%$ concentrations were highly toxic to bees; twice the number

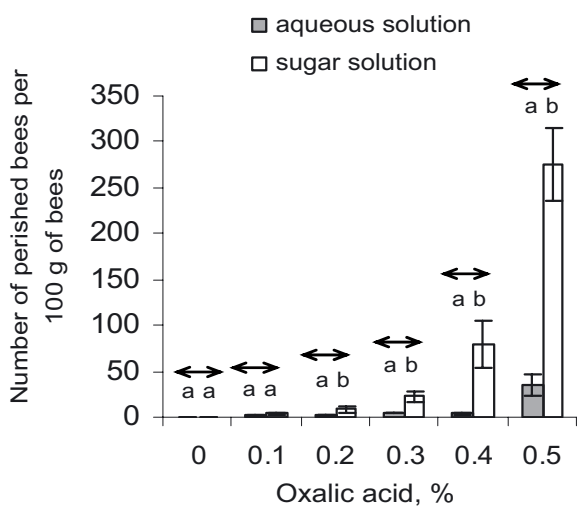

Figure 3. Effect of $0.1-0.5 \%$ oxalic acid dihydrate in aqueous and in 50\% sucrose solution on bees in submersion tests ( $\mathrm{n}=5$ experimental series) at the end of July 2007. Different letters indicate statistically significant differences. As the concentration of OA increased above $0.2 \%$, the sucrose solution became increasingly more toxic to bees than the aqueous solution ( $t$-test, $P<0.05)$.

died (Fig. 5, $t$-test, $P<0.05$ ). In both groups, two of the three colonies were severely affected. The weakening was noticeable after the third and fourth spraying. In cool weather, dead bees were found in the hive behind the partition board and a few bees were seen to leave the hive, stagger and die in front of the entrance.

Experiment 4, in which bees in brood-free colonies were sprayed five times in May with a $0.5 \% \mathrm{OA}$ in aqueous solution at a dose of $25 \mathrm{~mL}$ per comb proved highly effective in mite control $(99.01 \pm 0.24 \%)$ and non-toxic to bees. The colonies did not weaken after spraying ( $t$-test, $\mathrm{t}=0.4246, P=0.6823)$.

Experiment 5, in which spray was applied five times in April with a $0.5 \%$ OA was similarly effective, $99.42 \pm 0.10 \%$. Most of the mites $(647.1 \pm 154.3$ or $78.3 \%)$ died within two days of the first spraying, fewer within two days of the second spraying $(139.6 \pm 23.7$ or $16.9 \%$ ), and very few after later sprayings (Fig. 6). However, 4 of the 11 test colonies weakened considerably, indicating toxicity of this treatment to bees. Noticeable weakening occurred after the fourth and fifth spraying, and was most noticeable 12 days later (Fig. 7, ANOVA, LSD test, $F_{3 ; 40}=10.2377, P=$ 


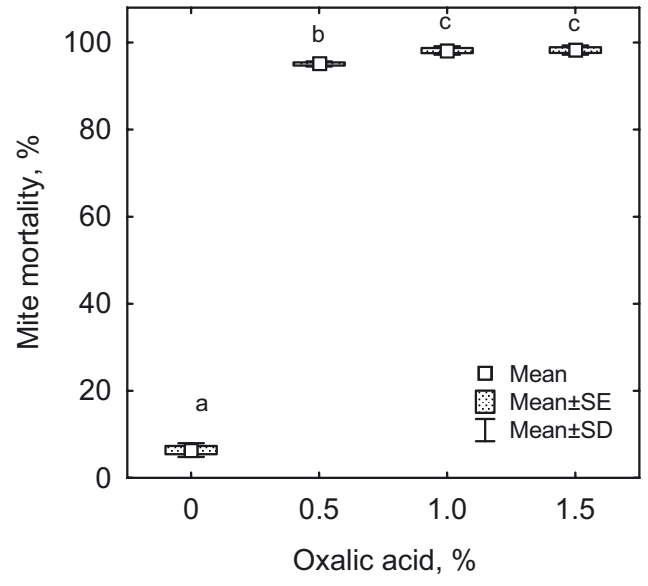

Figure 4. Effect of spraying bees in brood-free colonies in April 2003 with 0.5, 1.0 and 1.5\% oxalic acid dihydrate in aqueous solution four times on the mortality of Varroa mites (dose $25 \mathrm{~mL}$ per comb, $\mathrm{n}=3$ experimental series). Mean values marked with same letters do not differ significantly. The $0.5 \%$ concentration was significantly less effective than the 1.0 and $1.5 \%$ concentrations (ANOVA oneway, $\mathrm{LSD}$ test, $\mathrm{F}_{3 ; 8}=4466.64, P=0.000$ ).

0.00). In the control group colonies, no similar weakening occurred. The morning after the third spraying, a noticeable number (20-50) of dead bees were seen in front of the entrances of some test colonies. Following the fourth and fifth spraying, most of the test colonies had numerous dead bees in front of the entrance. In some colonies, bees showing toxic symptoms were seen to fly out of the hive, then fall and crawl in front of the hive.

Experiment 6 showed that spraying colonies with $0.5 \% \mathrm{OA}$ in aqueous solution, in September when they had little sealed brood, was highly effective in killing mites. Average efficacy in colonies sprayed once was $92.94 \pm 0.01 \%$ and in those sprayed twice, $91.84 \pm 0.02 \%$; in control groups only $5.41 \pm 0.01 \%$ (ANOVA, $\mathrm{F}_{3 ; 36}=683.96$, $P=0.00)$ of mites died. Treatment effects were smaller in colonies with more capped brood during spraying $(\mathrm{r}=-0.8276, \mathrm{n}=30)$. Thus there were 5 colonies in the test with $14.6-85.1 \mathrm{~cm}^{2}$ of capped brood and a treatment efficacy of $98.64-99.9 \%$. The same test included 11 colonies with $259.6-529.2 \mathrm{~cm}^{2}$

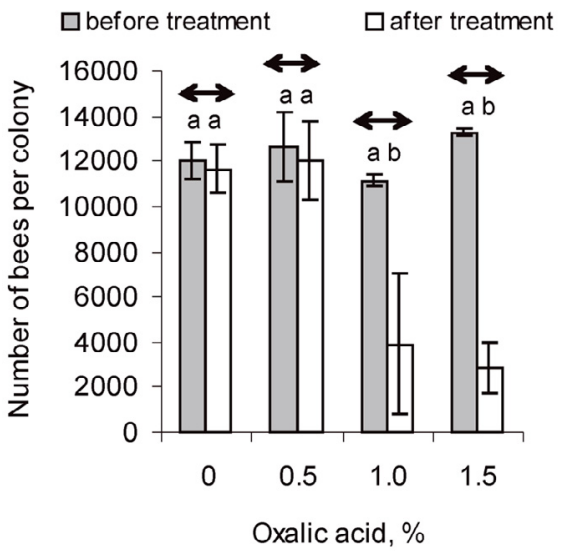

Figure 5. Effect on colony size of spraying bees four times in brood-free colonies in Spring 2003 with $0.5,1.0$ and $1.5 \%$ oxalic acid dihydrate in aqueous solution (dose $25 \mathrm{~mL}$ per comb, $\mathrm{n}=3$ experimental series). Mean values $( \pm \mathrm{SE})$ marked with different letters are significantly different.

The 1.0 and $1.5 \%$ concentrations weakened the colonies considerably $(t=2.3206, P=0.05$ and $t=9.3228, P=0.0007, t$-test $)$ whereas the $0.5 \%$ solution had no noticeable toxic effect ( $t=0.2579$, $P=0.8092, t$-test $)$.

of capped brood and a treatment efficacy of $86.16-89.67 \%$. Spraying once or twice with a dose of $25 \mathrm{ml}$ per comb proved non-toxic to bees; test colonies were no weaker than control colonies after the autumn spraying or the following spring (Fig. 8, ANOVA, LSD test, $P>0.05)$. The number of dead mites ranged from 436 to 9164 per colony, and on average $3329.74 \pm 500.94$ mites.

Experiment 7 showed that, although $0.3 \%$ $\mathrm{OA}$ in aqueous solution had relatively high efficacy in submersion tests (Experiment 2), this was not the case when bees were sprayed once with the same solution in the hive. The average effectiveness of spraying with $0.3 \%$ aqueous solution was $76.44 \pm 4.02 \%$, significantly lower than the 92 to $93 \%$ effectiveness obtained the previous autumn (Experiment 6) when spraying with the same dose of $0.5 \%$ solution ( $t$-test, $t=-5.6637, P=0.000 ; \mathrm{LSD}$ Test, $P=0.000)$. 


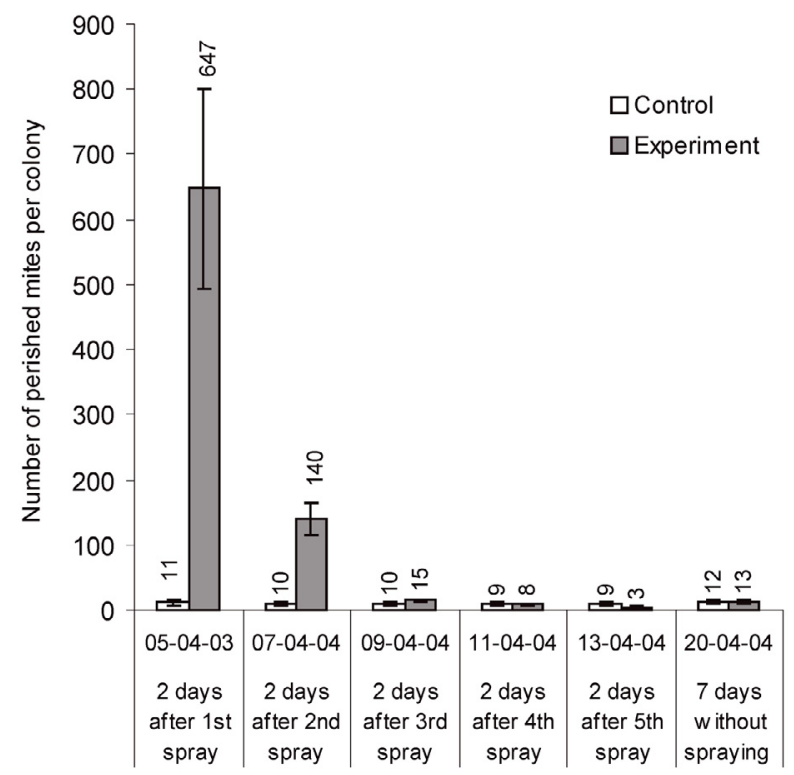

Figure 6. Dynamics of mite mortality in brood-free colonies after spraying the bees five times with $0.5 \%$ oxalic acid dihydrate in aqueous solution (dose $25 \mathrm{~mL}$ per comb, $\mathrm{n}=11$ ) in 2004. Data are presented as mean \pm standard error.

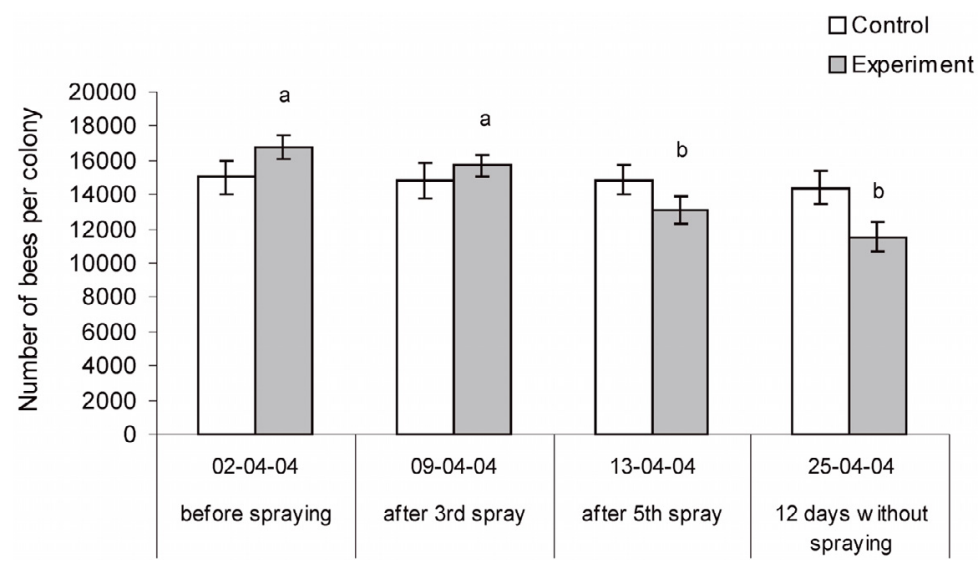

Figure 7. Effect on colony size of spraying bees five times in brood-free bee colonies (dose $25 \mathrm{~mL}$ per comb, $\mathrm{n}=11$ ) with $0.5 \%$ oxalic acid dihydrate in aqueous solution in Spring 2004. Different letters indicate statistically significant differences. Test colonies were weakened slightly more than the control colonies after the third spraying and considerably more after the fifth spraying. They continued to be weaker 12 days after the last spraying (ANOVA one-way, LSD test, $\mathrm{F}_{3 ; 40}=10.2377, P=0.000$ ).

\section{DISCUSSION}

\subsection{Submersion experiments}

The $0.5 \%$ OA in aqueous solution was as effective against mites as the 1, 1.5 and $2.0 \%$ solutions but was less toxic to bees
(Fig. 1). When caged bees were submerged into $0.1-0.5 \%$ aqueous OA solutions, even the $0.1 \%$ solution had a strong effect against the mite. Increasing concentrations to $0.2-0.3 \%$ substantially increased the effectiveness of mite control (Fig. 2A), but further increase from 0.3 to $0.5 \%$ did not raise mite mortality 


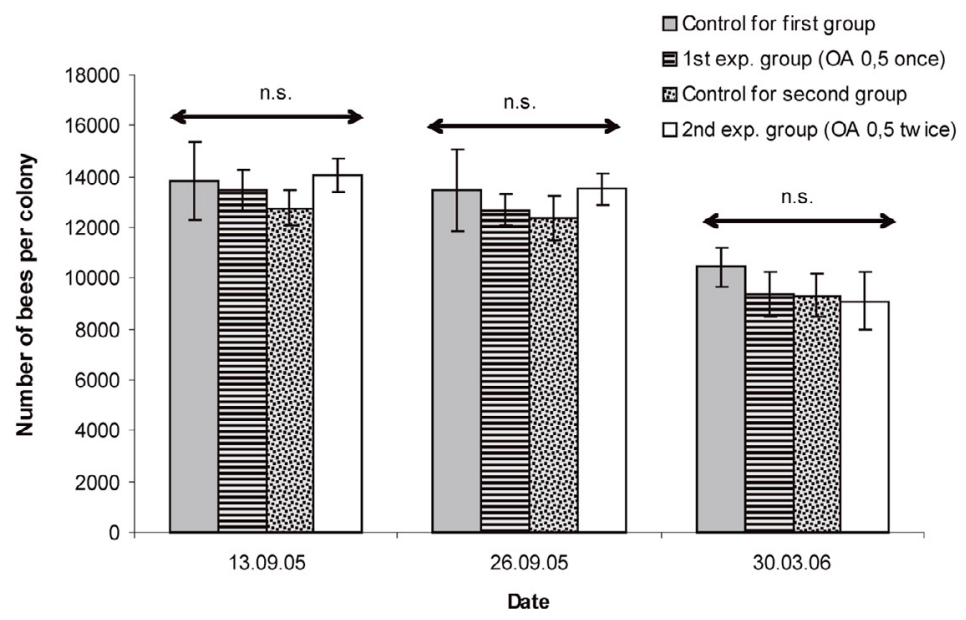

Figure 8. Effect on colony size of spraying bees in colonies containing a small amount of capped brood either once or twice with $0.5 \%$ oxalic acid dihydrate in aqueous solution (dose: $25 \mathrm{~mL}$ per comb, $\mathrm{n}=$ 15) in September 2005. Mean values marked with n.s. do not differ significantly. Test colonies were not significantly weaker than control colonies after spraying in autumn or in the following spring (ANOVA, LSD test, $P>0.05$ ).

(Fig. 2A). The same concentrations of OA in sucrose solution showed a similar rise in mite mortality (Fig. 2B). A slightly higher acaricidal activity was found only in the concentration of $0.1 \%$ in sucrose solution compared to the same concentration in aqueous solution (Fig. 2A, B). At the same time, the oxalic acid in sugar solution increased the toxic effect to bees at the lower concentrations of $0.2-$ $0.3 \%$. Oxalic acid concentrations of $0.4-0.5 \%$ increased the rapid death of bees in comparison with solutions without sugar in the treatment solution (Fig. 3). It is possible the sugar solution containing oxalic acid crystals stuck to the cuticle and spiracles of bees prolonging the toxic effect, whereas the water from an aqueous solution evaporated and the remaining oxalic acid crystals fell from the bees. In our submersion tests bees were equally wet in both aqueous and sucrose solutions.

A few studies have been conducted to compare the effects of water and sugar solutions. For example, adding sugar to a trickling solution of OA increased the effectiveness of controlling the mite from $92.5 \%$ to $97.5 \%$, thus only by $5 \%$ (Charriere, 2001).
Some researchers have established that lower sugar content in oxalic acid solution increased bee tolerance but decreased its effectiveness in mite control (Milani, 2001; Gregorc and Planinc, 2001; Charriere and Imdorf, 2002; Nanetti et al., 2003). In most cases solutions without sugar were not very effective, and 30\% sugar solutions tended to have slightly lower acaricidal efficacy compared to $60 \%$ sugar solutions (Nanetti et al., 2003). The importance of sugar in increasing the efficacy is still an open question and more tests are required using lower concentrations of sugar.

\subsection{Spraying experiments}

In spraying experiments, $0.5 \% \mathrm{OA}$ in aqueous solution was as effective as 1 and $1.5 \%$ solutions for mite control (Fig. 4) but was less toxic to bees (Fig. 5). Spraying five times with $0.5 \% \mathrm{OA}$ in aqueous solution in May 2003 was non-toxic to bees; colonies were as strong post-treatment as pre-treatment. Spraying five times in April 2004, however, was toxic to bees. The toxic effect was not significant after 
the first three sprayings and test colonies did not differ significantly from the control. A noticeable toxic effect was seen after the third, and particularly after further sprays (Fig. 7). One possible explanation is that in April 2004, compared to the experiment conducted in May 2003, the bees were less able to fly from the hive on cleansing flights due to cold weather; the cleansing flights might have helped rid the bees of oxalic acid residues. Furthermore, the bees in the experimental hives in April 2004 were comprised mainly of old overwintered individuals. The brood area was small, whereas by May, a new generation of bees had emerged before treatment. The test colonies were weakened by the death of old bees and shortage of young bees in 2004. Due to high efficacy of $0.5 \%$ OA for mite control, there was no need to treat more than twice as most of the mites died after the first and second spraying (Fig. 6).

Most mites died after the first spraying and a large number died after the second spraying as well (Fig. 6). As first and second sprayings were only two days apart, some of the mites presumably died as a result of the first spraying in our experiment. In submersion tests, about $90 \%$ of the mites fell within twenty-four hours presumably because they became completely wet. Higher doses of treatment solution may have led to better distribution of OA due to water improving the transfer and contact with OA, resulting in the more rapid death of mites. It has been recommended that experimental data should not be gathered for at least one week after spraying (Radetzki et al., 1994; Brødsgaard et al., 1999) as most mites fall during the week following a treatment (Brødsgaard et al., 1999). The experiment with $0.5 \% \mathrm{OA}$ in aqueous solution in autumn of 2005 showed that there was no difference in the effectiveness of control after spraying once or twice (ANOVA one-way, $\mathrm{F}_{3 ; 36}=683.96$, $P=0.00)$. The effectiveness of mite control increased as the area of capped brood in hives decreased $(\mathrm{r}=-0.8276, \mathrm{n}=30)$.

During experiment 6 (spraying once or twice with $0.5 \% \mathrm{OA}$ in aqueous solution) we observed large differences in the number of mites among different colonies within one apiary. The differences were greater than 10 times and, in some cases, even up to 20 times. This was also noted by Fries et al. (1991) who suggested the variation may be affected by several factors, such as differences in the actual initial dose of fertile mites, differences in broodrearing pattern between colonies, variation in mite fertility between colonies, differences in grooming behaviour between colonies, and possible uneven transfer of mites between colonies, in spite of precautions to avoid drifting.

Spraying once or twice with $0.5 \%$ OA in aqueous solution in September 2005 showed equally high efficacy of mite control and little toxicity to bees (Fig. 8). We conclude that a single spray of this concentration is sufficient to achieve adequate Varroa control. In our spraying experiments during the treatments in April, colonies had mainly capped honey and only a little fresh nectar from willows (Salix sp.) and coltsfoot (Tussilago farfara). In autumn, honey combs were capped and contact with OA-residues was also restricted. For this reason only a little amount of OA would contaminate the honey. Due to lower amount of OA in our treatments $0.125 \mathrm{~g}$ per comb (in $0.5 \%$ OA solution) compared with the experiments (in $3.0 \%$ OA solution $0.195 \mathrm{~g}$ per comb) of Radetzki et al. (1994) and Charrière and Imdorf (2002), the residues in honey would be even lower in our experiments. In Central European conditions it may prove possible to treat in November or even in December. As a sprayed concentration of $0.3 \%$ was less effective in practice, a concentration of $0.4-0.5 \%$ in aqueous solution at a dose of ca $25 \mathrm{~mL}$ per comb should be used. With the $0.5 \%$ solution, we must accept some death of bees, although this is small and may be acceptable. Spraying later, in autumn, when there is less brood in the hive, can increase its effectiveness. The treatment effect can also be increased by spraying bees on combs from different directions, i.e. wetting them as much as possible with an OA solution.

Some experiments have shown that a single spray with OA in aqueous or sucrose solution is considerably more effective than trickling (Brødsgaard et al., 1999; Bahreini, 2003), indicating that greater wetting of bees increases the effectiveness of the oxalic acid in mite 
control. Our submersion tests also showed the importance of thorough wetting for good mite control. A lower concentration may be considerably less effective in trickling due to less contact of the solution with the bees and mites. Fries (2001) found that trickling a $1.6 \%$ oxalic acid solution at a higher dose $(60 \mathrm{~mL}$ per colony) was $68.3 \%$ effective whereas a $3.25 \%$ solution, $30 \mathrm{~mL}$ per colony, was $92.2 \%$ effective. Although concentrations of $<4.6 \%$ have been tolerated well by bees in experiments by many researchers, in some experiments colonies have been weakened considerably following a single trickling treatment. Multiple autumn or summer treatments (two to three times) by trickling were poorly tolerated by the bees in Central Europe (Rademacher and Harz, 2006). These facts refer to the toxicity of the OA concentrations to bees used with the trickling method, which is not always revealed and depends, in all tests, on the individual tolerance of bee colonies. Concentrations, doses and efficacy of oxalic acid sugar concentrations less toxic to bees as well as the toxicity of the concentrations in their repeated use require further research.

The main advantage of treatment in the spring rather than in the autumn is the reduced danger of disturbance of colony homeostasis, especially of harm to the queen. Autumn treatment may disturb preparations for the wintering period. On the other hand, if the population of mites is high and autumn treatment for mite control considered essential it must be done carefully. Treatment by spraying is very laborious whereas the trickling method is more convenient in practice.

The spraying method is the most suitable in hobby beekeeping apiaries. Use of low spray concentrations of OA harmless to bees probably could be successfully integrated in normal beekeeping practice when there is no or only small areas of capped brood (eg. after hiving of swarms, broodless periods in swarmed colonies and nucleus colonies, after heavy honeydew flow and after honey harvesting with only a small amount of brood in the hive, in broodless periods in late autumn and early spring, or after use of the shaking against foulbrood diseases). Spraying with a weak so- lution of OA is less harmful to the honey bees and to the people applying the treatment.

\section{ACKNOWLEDGEMENTS}

The research was supported by the Estonian Sciences Foundation Grant No 7391 and Targeted financing SF 0170057s09. We are grateful to Marguerite Oetjen for English revision and for Sirje Mitt for help in statistical analysis and for technical support. We thank Peter Rosenkranz for editing and anonymous referees for their reviews.

Effet de l'acide oxalique dissout à différentes concentrations dans une solution d'eau distillée ou de sucrose sur le varroa et sur les abeilles.

\section{Apis mellifera / Varroa destructor / acide oxalique / toxicité}

Zusammenfassung - Der Effekt unterschiedlicher Oxalsäurekonzentrationen in Wasser- und Zuckerlösungen auf Varroamilben und Honigbienen. In dieser Untersuchung sollte diejenige Konzentration von Oxalsäure-Dihydrat (OS) ermittelt werden, die eine wirksame Varroakontrolle bei gleichzeitiger geringer Bienentoxizität sicher stellt. Von 2002 bis 2007 verglichen wir unterschiedliche OS-Konzentrationen in wässrigen Lösungen und Zuckerwasserlösungen, indem wir zunächst gekäfigte und mit Varroamilben befallene Bienen in die entsprechenden OS-Lösungen eintauchten. Daneben wurden Bienen in befallenen Bienenvölkern mit und ohne Brut mit OS- Lösungen besprüht. Die Anzahl der überlebenden Milben nach den Behandlungen wurde mit Apistan-Streifen ermittelt.

In den „Tauchtests“ waren wässrige OSKonzentrationen zwischen $0,5-2,0 \%$ toxisch für Milben, aber bereits Lösungen von $1 \%$ - und mehr noch die 1,5 - und 2,0-prozentigen Lösungen - waren auch für Bienen hochtoxisch (Abb. 1). In $50 \%$-iger Zuckerlösung war OS $(0,1-0,5 \%)$ bei $0,1 \%$ wirksamer gegenüber Milben (Abb. 2A, B) aber bereits bei Konzentrationen von 0,2-0,3\% auch toxischer gegenüber Bienen (Abb. 3).

In Sprühversuchen waren wässrige 1,0 und 1,5\% OS-Lösungen gleichermaßen toxisch für Milben $(98,4 \pm 0,01 \%$ und $98,3 \pm 0,01 \%)$, während eine 0,5 \%-ige Lösung einen schwächeren Wirkungsgrad hatte $(94,9 \pm 0,00 \%)$ (Abb. 4). Allerdings waren die 1,0- und 1,5\%-igen Lösungen sehr toxisch für Bienen (Abb. 5). Frühjahrsbehandlungen, bei denen brutfreie Bienenvölker fünfmal mit einer $0,5 \%$-igen wässrigen OS-Lösung mit $25 \mathrm{ml}$ pro Wabe besprüht wurden, ergaben einen durchschnittlichen Wirkungsgrad von $99,0 \pm 0,24 \%$. 
Die meisten Milben starben dabei nach der ersten Behandlung (Abb. 6). Jedoch war die fünfmalige Sprühbehandlung im Frühjahr toxisch für Bienen (Abb. 7). Ein- bis zweimalige Herbstbehandlungen von Bienen in Völkern mit wenig verdeckelter Brut mit 0,5 \%-iger OS-Lösung zeigten mit $92,9 \pm 0.01 \%$ bzw. $91.8 \pm 0.02 \%$ fast den gleichen Effekt (Abb. 8) und blieben ohne erkennbare Toxizität gegenüber den Bienen (Abb. 8). In Bienenvölkern mit einem größeren Umfang an verdeckelter Brut waren die Behandlungen weniger effektiv.

Wir schließen aus unseren Versuchen, dass mit einer 0,5\%-igen wässrigen OS-Lösung, die einmal auf Bienen in Völkern ohne oder mit wenig Brut gesprüht wird, eine gute Wirksamkeit gegenüber den Varroamilben bei gleichzeitigen geringen Bienenschäden erreicht wird.

\section{Apis mellifera / Honigbiene / Varroa destructor / Oxalsäure}

\section{REFERENCES}

Bahreini R. (2003) A comparison of two methods of applying oxalic acid for control of varroa, J. Apic. Res. 42, 82-83.

Brødsgaard C.J., Jensen S.E., Hansen C.W., Hansen H. (1999) Spring treatment with oxalic acid in honeybee colonies as varroa control, DIAS report, Horticulture 6, 1-16.

Charrière J.D. (2001) Optimisation of the oxalic acid trickling method and bee tolerability of different winter treatments: trials in Liebefeld during the last 3 years, Meeting of the European Group for Integrated Varroa Control, York, http://www.apis. admin.ch/host/varroa/york.htm.

Charrière J.-D., Imdorf A. (2002) Oxalic acid treatment by trickling against Varroa destructor: recommendations for use in central Europe and under temperate climate conditions, Bee World 82, $51-60$.

Fries I. (2001) Is the total amount or the concentration of oxalic acid critical for efficacy in varroa mite control? European Group for Integrated Varroa Control, York, http://www.apis.admin.ch/ host/varroa/york.htm.

Fries I., Aarhus A., Hansen H., Korpela S. (1991) Development of early infestations by the mite Varroa jacobsoni in honey-bee (Apis mellifera) colonies in cold climates, Exp. Appl. Acarol. 11, 205-214.

Gerig L. (1983) Lehrgang zur Erfassung der Volksstärke, Schweiz. Bienen-Zeitung 106, 1099-2004.
Gregorc A., Planinc I. (2001) Acaricidal effect of oxalic acid in honeybee (Apis mellifera) colonies, Apidologie 32, 333-340.

Gregorc A., Pogaènik A., Bowen I.D. (2004) Cell death in honeybee (Apis mellifera) larvae treated with oxalic acid or formic acid, Apidologie 35, 453-460.

Hatjina F., Haristos L. (2005) Indirect effects of oxalic acid administered by trickling method on honey bee brood, J. Apic. Res. 44, 172-174.

Higes M., Aránzazu M., Suèárez M., Llorente J. (1999) Negative long-term effects on bee colonies treated with oxalic acid against Varroa jacobsoni Oud., Apidologie 30, 289-292.

Imdorf A., Buehlmann G., Gerig L., Kilchenmann V., Wille H. (1987) Überprüfung der Schätzmethode zur Ermittlung der Brutfläche und der Anzahl Arbeiterinnen in freifliegenden Bienenvölkern, Apidologie 18, 137-146.

Imdorf A., Charriere J.-D., Bachofen B. (1997) Efficiency checking of the Varroa jacobsoni Control methods by means of oxalic acid, Apiacta 32, 89-91.

Milani N. (2001) Activity of oxalic and citric acids on the mite Varroa destructor in laboratory assays, Apidologie 32, 127-138.

Mutinelli F., Baggio A., Capolongo F., Piro R., Prandin L., Biasion L. (1997) A scientific note on oxalic acid by topical application for the control of varroosis, Apidologie 28, 461-462.

Nanetti A., Büchler R., Charriere J.-D., Fries I., Helland S., Imdorf A., Korpela S., Kristiansen P. (2003) Oxalic acid treatments for varroa control (review), Apiacta 38, 81-87.

Nanetti A., Massi A., Mutinelli F., Cremasco S. (1995) L'acido ossalico nel controllo della varroasi: note preliminari, Apitalia 22, 29-32.

Rademacher E., Harz M. (2006) Oxalic acid for the control of varroasis in honey bee colonies-a review, Apidologie 37, 98-120.

Radetzki T., Reiter M., Negelein B., Fischermühle H. (1994) Oxalsäure zur Varroabekämpfung, Schweiz. Bienen-Zeitung 117, 263-267.

Takeuchi K., Harada K. (1983a) Control of Varroa jacobsoni mites with oxalic acid spray, Honeybee Science 4, 113-116 (in Japanese).

Takeuchi K., Sakai T. (1983b) Varroatose-bekämpfung mit Oxalsäure, Apimondia, Der XXIX. Internationale Bienenzüchterkongress, Budapest, Ungarn 25.-31. Aug., Bukarest, p. 202.

Takeuchi K., Sakai T. (1985) Possible combination of three control measures for varroasis, Proceedings of the XXXth International Congress of Apimondia, Nagoya, Japan, 10-16 oct., Apimondia Publ. House, Bucharest, pp. 202-206. 